\title{
総 括
}

（1）A. agile ATCC 9046 を用いロイシンのよ5なアミノ酸に対する酸化能は適応的に発現し得ないが，炭 素源によっては生育を著しく阻害するアミノ酸のあることを明かにした。

（2）この菌の磨破摽品は多くのアミノ酸を酸化し得ないが，TCA 系から直接誘導されるアミノ酸ではやや 酸化が認められる.併しグルタミン酸は例外的に強い酸化をうける。このことからグルタミン酸々化機作検討の 重要性について論じた.

御䁅篤な指導を頂いた植村教授に厚く謝意を表します。又御批判と激励を与兄られた古城教授，尾田助教授， 御協力を頂いた研究室の諸兄㭏に感詂します。

(1) 復藤恒二： 本誌, 31，239 (1957).

(2) 前田喜美子, 宇佐美正一郎：醉素化学シン ポシウム, 10, 228 (1954).

(3) E. R. Roberts, et al. : Biochim. Biophys. Acta, 14, 85 (1954) ; 14, 507 (1954) ; 15, 568 (1954); 21, 308(1956); 21, 562(1956).

(4) M.F. Utter, C.H. Werkman : Biochem. $J ., 36,485$ (1932).
（5）宇佳美正一郎, 他：生物科学, 谁化特集 49 (1954).

(6) W. E. Magee, R.H. Burris : J. Bacteriol., 71,635 (1956).

(7) J. E. Greaves, et al. : Soil Sci., 49, 9 (1940).

(8) M. Alexander, P.W. Wilson : J. Bacteriol., 71, 252 (1956).

\section{黒麴菌の Amylolytic System に関する研究 (第 3 報)*}

\section{各種生澱粉の糖化とアミラーゼ吸着との関係について}

上田 誠 之助（九州大学嶩学部農芸化学教室）

昭和 32 年 5 月 24 日受理

緒容

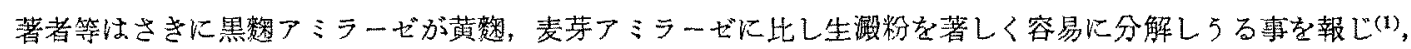
更にアミラーゼ系を粕化型及び液化型区分に分取し，その糊化澱粉及び生囹粉の糖化機構を調べだ(2,3)．本報で

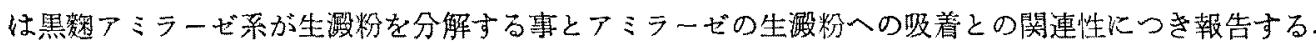

アミラーゼが生激粉に吸着される事は古くから知られ，Holmberg は麦芽の $\alpha$-及び $\beta$ 及ーアミーゼの分別化

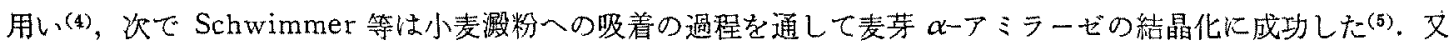
同氏等は各種生澱粉の麦芽 $\alpha-$ アララーゼ吸着能が搌粉粒の大小に逆比例する事を報じている(6)。德剛(7)は蒸米

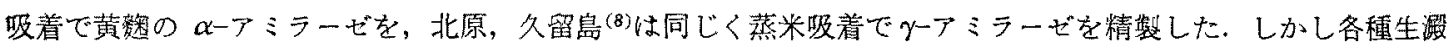
粉の糖化の難易とアミラーゼ吸着との関係についての報文には接しないのでここに報告する.

\section{实 験 $\odot$ 部}

試料玉蜀禁，甘藷，馬鉿薯の各澱粉は日本澱粉株式会社より恵与されたものを更に数回蒸溜水にて洗滌し，

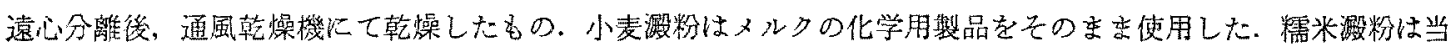

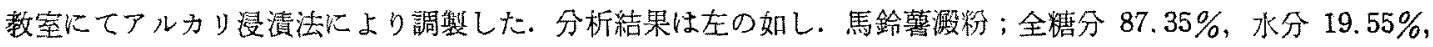

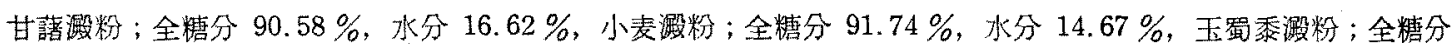
$88.41 \%$ ，水分 $16.21 \%$ ，糯米澱粉；全精分 $90.98 \%$ ，水分 $14.83 \%$.

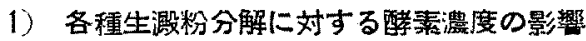

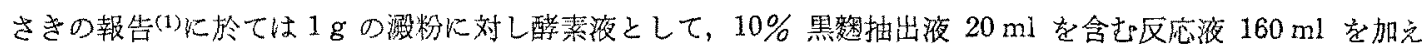

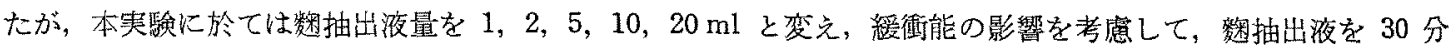

\footnotetext{
* Studies on the Amylolytic System of the Black-koji Molds. Part III. Relationship between the Susceptibility to Digestion and the Efficiency of Adsorption of Black-koji Amylase by Raw Starch.

By Seinosuke UEDA (Department of Agricultural Chemistry, Faculty of Agriculture, Kyushu University)
} 


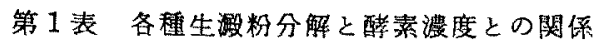

\begin{tabular}{|c|c|c|c|c|c|c|}
\hline 区店 & $(\mathrm{m}$ & 1 & 2 & 5 & 10 & 20 \\
\hline & 16 & 0.024 & 0.035 & 0.080 & 0.146 & 0.26 \\
\hline & 40 & 0.122 & 0.180 & 0.374 & 0. & 0.741 \\
\hline & 64 & 0.197 & 0.338 & 0.622 & 0.787 & 0.88 \\
\hline & 112 & 0.346 & 0 & 0. & & 0.88 \\
\hline & 16 & 0.030 & 0.042 & 0.107 & 0. & 0.168 \\
\hline & 40 & 0.066 & 0.117 & 0.243 & 0. & 0.346 \\
\hline & 88 & 0.157 & 0.235 & 0.418 & 0. & 0.632 \\
\hline & 112 & 0.197 & 0. & & & 0.758 \\
\hline & 16 & 0.029 & 0.034 & 0.039 & 0.043 & 0.06 \\
\hline & 40 & 0.050 & 0.058 & 0.068 & 0.084 & 0.106 \\
\hline & 64 & 0.061 & 0.075 & 0.092 & 0.129 & 0.134 \\
\hline & 112 & 0.066 & 0.096 & 0.118 & 0.138 & 0.176 \\
\hline
\end{tabular}

間惹沸し，冷却後原容に帰したものを夫々 19,18 , 15，10，0 ml 添加し，更に前回同様綏衝液 $20 \mathrm{ml}$ ，水 道水 $120 \mathrm{ml} ，$ トルオール $1 \mathrm{ml}$ を加党 $30^{\circ}$ にて反応 せしめた，所定時間後の還元力の增加を $1 \mathrm{~g}$ 澱粉より の生成葡萄糖 $\mathrm{g}$ 数として計算した. 結果は第 1 表汇示 した。

今 40 時間に於ける各種生汼粉よりの生成糖々醉素 濃度との関係を図示せば第 1 図の如し.

第1図より明かな様に，糖化されやすい玉蜀録䀧粉

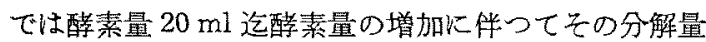
を增すむ，甘藷激粉では酵素量 $5 \mathrm{ml}$ 迄は醉素量の增 加伴つて分解量を增し，それ以上の䤃素量では分解 量の增加が著しく少くなる．最も糖化されにくい馬鈴 薯澱粉では䤃素濃度の增加による分解量の增加が極め て少い事が判明した。この事より各種生測粉間に見ら れる被糖化性の難易は醅素の激粉に対する親和力の大 小に比例しているのてはないかと思われる．即ち最も 糖化されにくい馬鈴薯澱粉では既に酵素量 $1 \mathrm{ml}$ で飽 和され，甘墸激粉では $5 \mathrm{ml}$ にて飽和され，三者の中

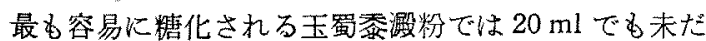
酵素に対する親和力は残つているものと思われる。こ の親和力がアミラーゼの生滶粉への吸着と関係がある ものか否かを究明する。

\section{2）吸着アミラーゼの糖化作用}

吸着操作：玉蜀㯟澱粉 $1 \mathrm{~g}$ に黑嵝抽出夜 $10 \mathrm{ml}$,

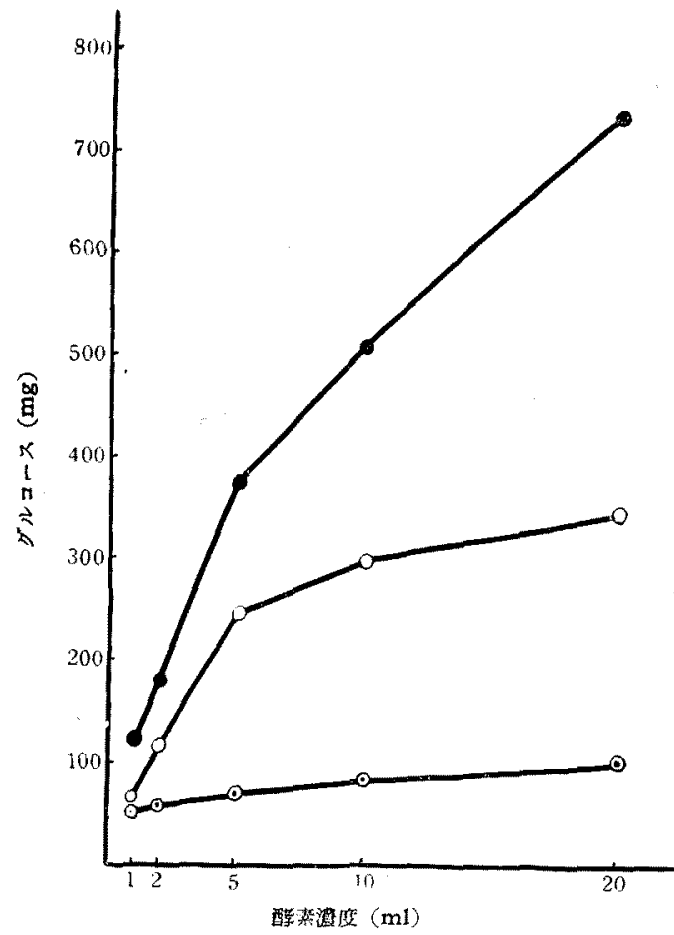

第 1 図 各種生澱粉の分解之酵素浂度之の関係

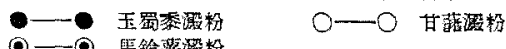

第 2 表 吸着アミラーゼに上方生敗粉糖化の反応液 組成

$\begin{array}{lllllllll}\text { 実 娩 采 } & \text { 列 No. } & 1 & 2 & 3 & 4 & 5 & 6 & 7\end{array}$

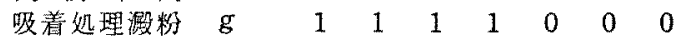

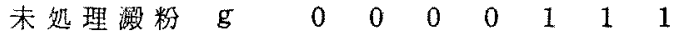

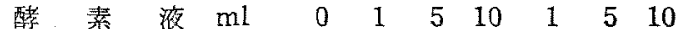

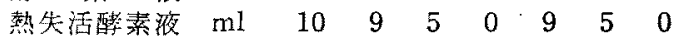

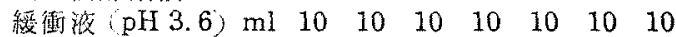

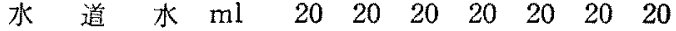
$\begin{array}{lllllllll}\text { 全 } & \text { 容 } \mathrm{ml} & 40 & 40 & 40 & 40 & 40 & 40 & 40\end{array}$ 各タトルオール $0.5 \mathrm{ml}$ 添加

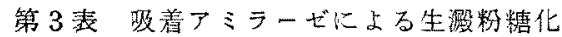

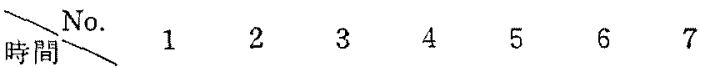

$\begin{array}{llllllllll}16 & 0.391 & 0.426 & 0.493 & 0.505 & 0.137 & 0.356 & 0.500\end{array}$ $\begin{array}{llllllllll}40 & 0.782 & 0.804 & 0.828 & 0.828 & 0.288 & 0.702 & 0.821\end{array}$ $\begin{array}{llllllllll}60 & 0.872 & 0.886 & 0.876 & 0.876 & 0.456 & 0.875 & 0.884\end{array}$ Total $0.884 \mathrm{~g}$

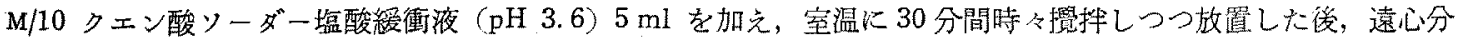

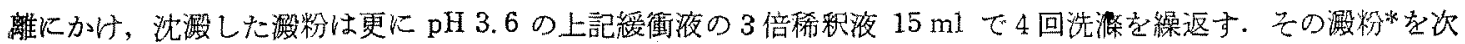
の第 2 蒜に示可組成の実験に供した。

上記組成の反応液を $30^{\circ}$ に保ち所定時間後還元力の堌加を澱粉 $1 \mathrm{~g}$ よりの葡萄糖 $\mathrm{g}$ 数であらわした. 結果は第 3 表の如し.

第 3 表より明かな様に澱粉に吸着されたアミラーゼ（No.1，2，3，4）吕生洪粉の糖化に関与寸る事を知った.

\section{3）弫粉粒子の大小と生澱粉の糖化の難易}

*この澱粉の附着水は予め科量した遠心管の使用により䛠算し，それだ加える水量を加減した。 
さきに Schwimmer 等(6)は麦芽 $\alpha$-アミラーゼの生溉粉への吸着の場合, 澱粉の表面糟の大なるもの程アミラ 一ゼをよく吸着する事を報じている，前節に於て甴着アミラーゼが生澱粉を分解する事を知ったので，果して生 澱粉の分解の難易が粒の大小に比例するや否やを检討した。

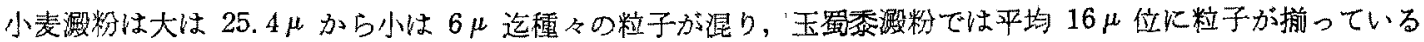

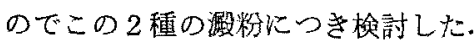

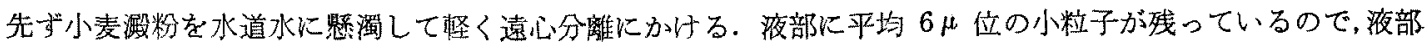
と沈澱部とを別々に乾燥し，試験に供した．生溉粉分解の反応液の組成は既報(1)の如し. 但しこの場合は比較の

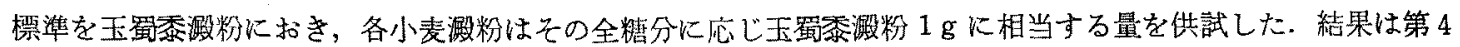
表に示した:

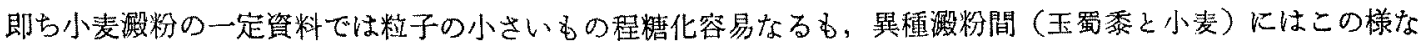

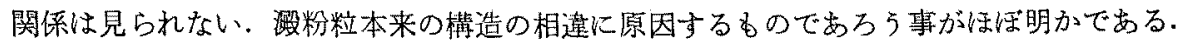

第 4 表 澱粉粒子の大小と生澱粉の糖化の難易

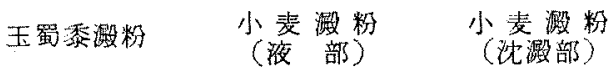

$\begin{array}{cccc}\text { 反応 } & \text { 粒子值 } \\ \text { 時) } & 8.4 \sim 19.6 & 6 & 6 \sim 25.4 \\ 23 & 0.256(29.0 \%) & 0.246(27.8 \%) & 0.184(20.8 \%) \\ 47 & 0.560(63.3 \%) & 0.598(67.6 \%) & 0.408(46.1 \%) \\ 67 & 0.746(84.4 \%) & 0.782(88.4 \%) & 0.564(63.8 \%)\end{array}$

第 5 表 各種生澼粉の吸着アミラーゼ量の比较

吸着用

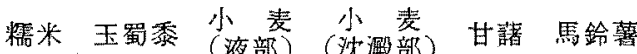

反応、径 $(\boldsymbol{\mu})$ $5.6 \sim 8.4 \sim$ $7 \quad 19.6$ $6 \quad 6 \sim \quad 12 \sim 40 \sim$ 凉照
( 吸着
醉案液) 時䦓

$\begin{array}{lllllll}22 & 0.076 & 0.102 & 0.102 & 0.118 & 0.146 & 0.216 \\ 46 & 0.160 & 0.213 & 0.220 & 0.248 & 0.317 & 0.398\end{array}$

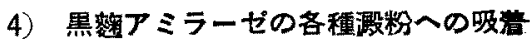
澱粉資料には糯米，玉置霡，小麦(液部)， 小麦(沈澱部)，甘藷，馬鈴薯の各洪粉を使 用した。これら瞰粉の生檓粉糖化の難易は 既報 ${ }^{(1,2)}$ の如く, 列記順に粕化容易な測粉 から因奞当澱粉に至る。

吸着要領：前々節に同じ。吸着度合を胃 るため，吸着残液の玉蜀霜生㴘 粉糖化力索比較した，反㐫液の 組成：吸着残液 $10 \mathrm{ml}, \mathrm{M} / 10$ 夕 エン酸ソーダー塩酸緩衝液 $(\mathrm{pH}$

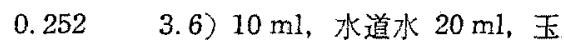
0.442 全粕 $0.442 \mathrm{~g}$

第 6 表 黑数丁ミラーゼの生激粉糖化と $\mathrm{pH}$ との関係

1) アミラーゼ吸着澱粉

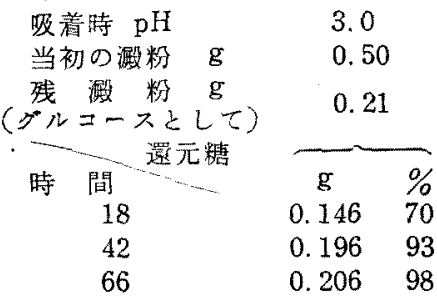

2) アミラーゼ吸程残夜

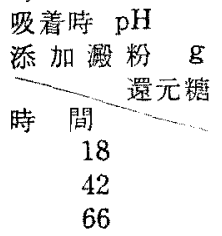

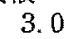

0.25

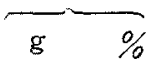

$0.066 \quad 29$

$0.157 \quad 70$

$0.224 \quad 100$

3) $\mathrm{pH}$ 安定度 $\mathrm{pH}$

添加檓粉 $\mathrm{g}$

時 䦓 還元敉

16

41

65
3.0

0.25

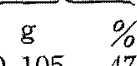

$0.105 \quad 47$

0. $206 \quad 92$

0. $220 \quad 98$
3. 6

0. 50

0.20

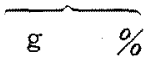

$0.152 \quad 76$

0.19698

0.19698
4. 2

0.50

0.26

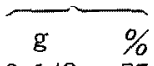

0.14355

$0.213 \quad 82$

$0.260 \quad 100$
5. 0

0.50

0.43

$\begin{array}{cc}\mathrm{g} & \% \\ 0.052 & 12 \\ 0.095 & 22 \\ 0.155 & 36\end{array}$

6. 0

0.50

0.46

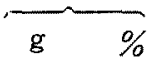

$0.037 \quad 8$

$0.069 \quad 15$

0.11525
4. 2

0.25

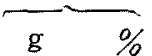

$0.067 \quad 30$

0.17377

0. $226 \quad 101$
0.25

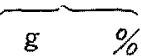

$0.088 \quad 39$

$0.189 \quad 84$

$0.226 \quad 101$

\section{0}

$$
0.25
$$

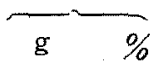

$0.139 \quad 62$

0.21194

0.224100
6. 0

0.25

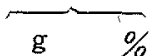

0. 12355

0,20290

$0.225 \quad 100$
7. 0

0.50

0. 46

\begin{tabular}{ll}
\hline $\mathrm{g}$ & $\%$ \\
0.009 & 2 \\
0.024 & 5 \\
0.032 & 7
\end{tabular}

3. 6

0.25

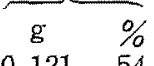

$0.121 \quad 54$

0.21596

0.22299
4. 0

0.25

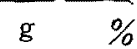

$0.125 \quad 56$

0. $217 \quad 97$

0. $224 \quad 100$
5. 0

0.25

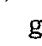

0.116

0. 206

0. 22299
6.0

0.25

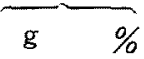

$0.099 \quad 44$

$0.204 \quad 91$

0.224100
7. 0 0.25

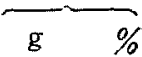

$0.038 \quad 17$

$0.060 \quad 27$

0. $089 \quad 40$ 


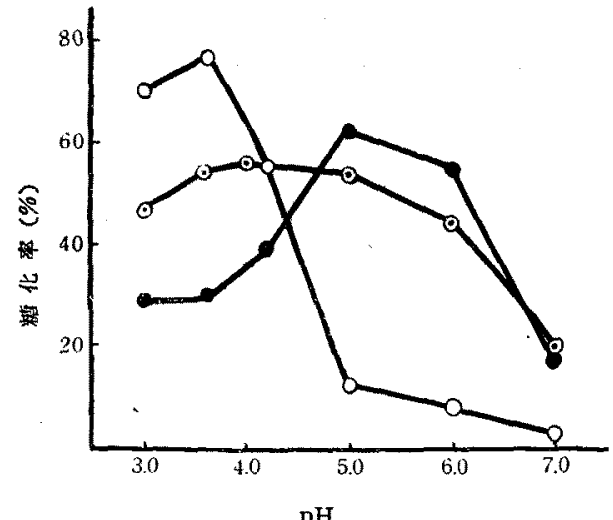

第 2 图 黑数アミテーゼの生晸粉への级塑と $\mathrm{pH}$ と口閣係

(但し吸着フミラーゼ，吸着残フミラーゼの䀛

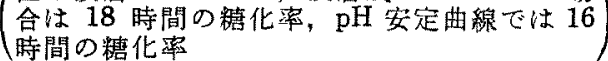

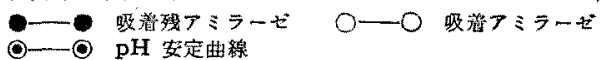

化を行わせ，残存の醉素力を測った。
$0.5 \mathrm{ml}$ ，反底跀䢛快第 5 表の如し.

この表から明かな様に糖化されやすい生澱粉程アミ ラーゼをより多量に昅着することが明かとなった。

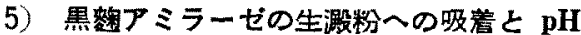

吸着操作は前節に潐じ，玉置愁生潵粉を使用し，種 々の pHにて吸着せしめた。吸着温度，吸着時間は生 測粉分解条件と同じにするため $30^{\circ}$ にて 18 時間吸着 せしめた。

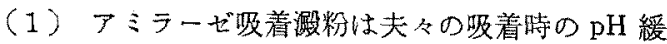
衝液の3 倍稀彩液 $15 \mathrm{ml}$ で8回洗淡し。これを $\mathrm{pH} 3.6$

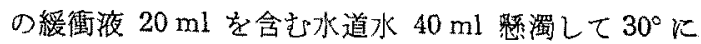
て結化を行就せた。

（2）吸着残夜は吸着の間に生成された摆元糖をミ クロヘルトラン法にて定量し，それに応じて各残部に 略同濃度の糖分を含む様に䓢萄糖を補添した後, 各 10 $\mathrm{ml}$ ずつ老㖟衝液で $\mathrm{pH} 3.6$ に揃光，水道水で全容 40 $\mathrm{ml}$ となし，无置禁生澱粉 $0.25 \mathrm{~g}$ を加え， $30^{\circ}$ にて糖

（3）対照：各 pH の酵素液を玉罢漆澱粉を加えず、トルオールのみを加えて，30に18時間静置したものの 安定度を調べた。結果は第 6 表及び第 2 図の如し.

以上の事実より黑䊍アミラーゼの生澱粉楉化の至適 $\mathrm{pH}$ は 3.6 附近で而もとの $\mathrm{pH}$ でアラーゼがよりよく生 濒粉に吸着される事る知っだ.

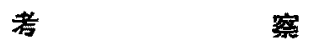

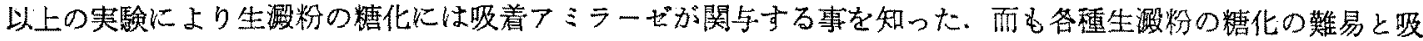

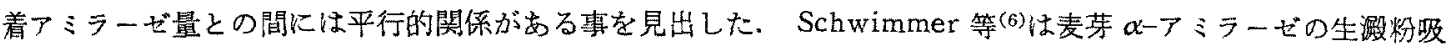

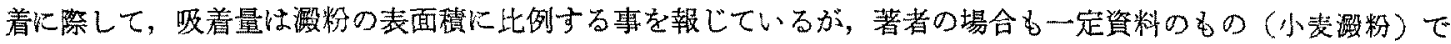

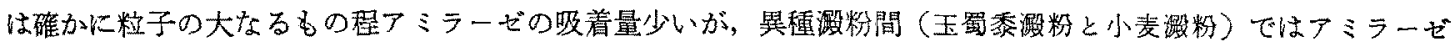
吸着量は各種澱粉特有の棈造に由来し，容易に糖化される搌粉珪アミラーゼをよく吸着する事を知った。而して Schwimmer 等は糯玉蜀霡䬦粉が粒子の表面筧の割に異常に高いアミラーゼ吸着能を有をる事を例外としている

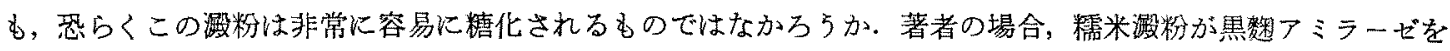

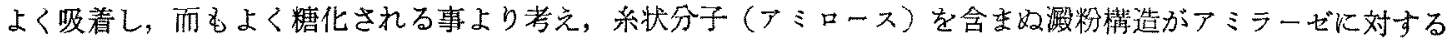
吸着性，被糖化性と関連性がある様に思觉る。然しながらアミロースを $21 〜 24 \%$ 含しといわれている(9)馬鈴 薯，玉蜀黍の两洪粉間に黑整アミラーゼに対する著しい態度の相異が見られる事は激粉粒の構造中に於けるアミ ロースの存在様式が問題となるのではなから5か.又，アミラーゼの澱粉への吸着が单なる吸着か，醉素一基質 複合体の如きるのか使に考究を要する問題である。

黒婪匋アミラーゼを生澱粉に作用せしめ次の事が明がなった。

（1）生激粉の糖化は吸着アミラーゼにより行われる.

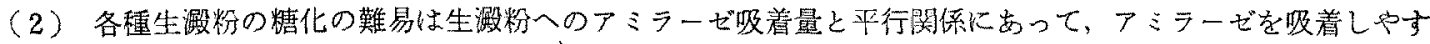

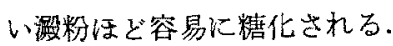

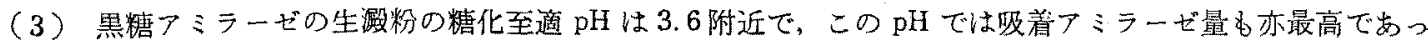
た.

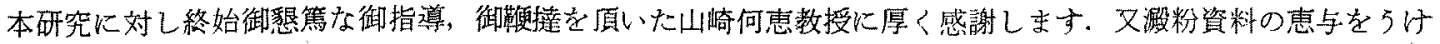
た日本澌粉株式会社に深謝します。 
（1）山踰何惠,上田誠之助：本誌, 24, 181 (1951).

(2) S. Ueda : Bull. Agr. Chem. Soc. Japan, 20, $148(1956)$.

(3) S. Ueda : Bull. Agr. Chem. Soc. Japan, 21, No. 5 (1957).

(4) O. Holmberg: Biochem. Z., 258, 134 (1933).

(5) S. Schwimmer, A. K. Balls: J. Biol.
Chem., 176, 465 (1948).

(6) S. Schwimmer, A. K. Balls : J. Biol. Chem., 180, 883 (1949).

(7) 德岡有三：本誌，13，586 (1937).

(8) 北湶觉雄, 久留島通佼：酸工, $28,442(1950)$.

(9) F. L. Bates, D. French, R. E. Rundle : J. Am. Chem. Soc., 65, 142 (1943).

\title{
黒麴菌の Amylolytic System 亿関する研究（第 4 報)*
}

\author{
各種黒麴菌による生澱粉の糖化 \\ 上田誠之助（九州大学滞学部费芸化学教室） \\ 昭和 32 年 5 月 24 日受理
}

\section{緒 言}

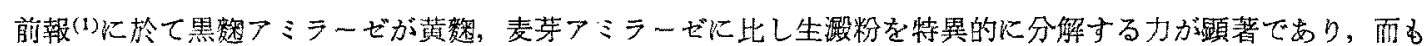
吸着アミラーゼが糖化に関与する事 ${ }^{(2)}$ を報じたが，本報では当教室保管の黑数菌数株につき澱粉溶液糖化力と生 澱粉分解力とを比較した結果を報告する.

\section{実験 の 部}

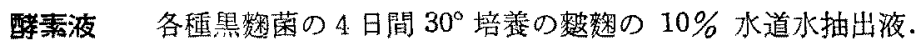

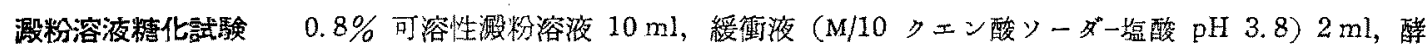
素液 $2 \mathrm{ml}$, 全容 $14 \mathrm{ml}, 50^{\circ} \mathrm{C}$ にて区応せしむ. 5 分, 10 分後の還元力の增加を反応液 $1 \mathrm{ml}$ につきミクロベル トラン法で葡萄糖として定睹した、又同時に反応液の沃度呈色反応を检した。

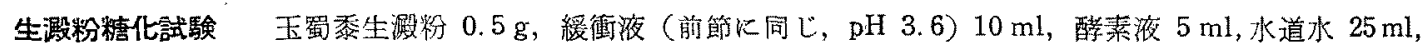
全容 $40 \mathrm{ml}$ に更にトルオール $1 \mathrm{ml}$ を加え $30^{\circ}$ にて反応せしめ, 所定時間後, 反応濾摭 $1 \mathrm{ml}$ につきタロべ ルトラン法にて還元力の增加を葡萢糖 $\mathrm{mg}$ にて示した。

\section{供試菌}

No. 1 Aspergillus Saito

No. 2 Aspergillus niger ( $\mathrm{K} 221$ )

No. 3 Aspergillus niger (K 222)

No. 4 Aspergillus niger

No. 5 Aspergillus batatae Saito

No. 6 Aspergillus Usamii

No. 7 Aspergillus Kinjyo

No. 8 Aspergillus awamori Nakazawa

No. 9 Aspergillus awamori var. kawachii

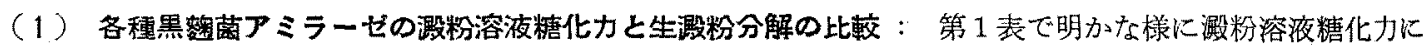

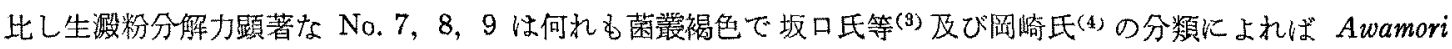

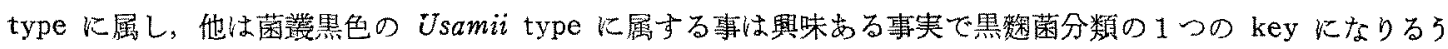
ろのではないかと考えられるも更に多数の黑整菌につき精查したい.

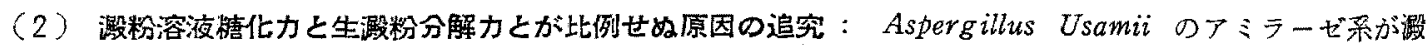
粉溶液の糖化力，液化力共に Aspergillus awamori var. kawachii K勝るにもかかわらず，生洪粉分解力が少 る原因を追究した，第 3 報(2)に於て生激粉分解に与るアミラーゼは主として吸着アミラーゼである事を知ったの で，两菌株につき吸着アミラーゼによる生澱粉分解を比較した.

\section{（1）吸着アミラーゼによる生澱粉分解 两菌株の醉素液は前節力洒のものを使用した．生澱粉分解の至適}

\footnotetext{
* Studies on the Amylolytic System of Black-koji Molds. Part IV. Comparative Study of
} Various Black-koji Molds on Raw Starch Digestion.

Seinosuke UEDA (Department of Agricultural Chemistry, Faculty of Agriculture,

Kyushu University) 